\title{
Types of Landslides along Lake Balaton, Hungary
}

\author{
Fruzsina Kápolnainé Nagy-Göde ${ }^{1}$, Ákos Török ${ }^{1 *}$ \\ 1 Department of Engineering Geology And Geotechnics, Faculty of Civil Engineering, Budapest University of Technology and Economics, \\ H-1521 Budapest, P.O.B. 91, Hungary \\ *Corresponding author, e-mail: torok.akos@emk.bme.hu
}

Received: 20 May 2021, Accepted: 16 December 2021, Published online: 17 January 2022

\begin{abstract}
Landslides are often triggered by various mechanisms such as precipitation, increase in the groundwater table, surface load, etc. and are classified according to the geometry and intensity of the motion. This paper provides an inventory considering all these factors by interpreting landslide records and available maps of the lakeside banks of the largest lake in Central Europe, Lake Balaton. Landslides in these areas severely damaged roads and railway networks. These disasters are linked to the mass movements of hundreds of m3 in the past years. The study area, the coastal regions of the lake, is divided into three geographically and geologically different sections (Eastern Basin, North Coast, South Coast). The landslide forms and the proportion of various movements and their timing also differ in these areas: at the south coast, falls and toppling prevail, while in the eastern basin, slidings prevail. The leading cause of mass movements is soaking and human interventions in all areas. Continuous monitoring of these landslide-prone areas contributes to the prediction of sliding and help in the design of remediation actions.
\end{abstract}

\section{Keywords}

coastal slope, mass movement, landslide hazard map, surface movement cadaster, soaking

\section{Introduction}

Coastal slopes (also called cliffs) are often subject to active erosion processes linked to their morphology, which then results in rapid stability changes [1]. Several erosion processes may include active slope toe erosion that initiates other processes such as surface erosion and landslides [2]. Shoreline erosion and cliff recession along most of the Great Lakes results in losses in millions of dollars annually in the form of infrastructure and property damage [3]. Various landslide forms are known, and their morphology reflects the broad occurrence [4].

The susceptibility of an area to landslides can be assessed using various methods such as mapping morphology [5] using remote sensing techniques $[6,7]$ or computing using different computer codes $[8,9]$. The present paper uses a statistical approach. It collects available data on the past landslides of the Lake Balaton coastal zone, an area where many past examples of slope failure have been documented since the $19^{\text {th }}$ century [10]. Besides recording past events, several research projects have been dealt with the stability issues of the steep slopes and shorelines of Lake Balaton. A number of interventions have been made to protect these coastal sections and their environment. However, due to the nature of coastal slopes, environmental factors, and funding issues, long-term and complete stability cannot be achieved in these areas and would not be economical. Lack of securing stability and sufficient funding to do so are the main reasons for uncontrolled slope failures. To ensure slope stability a continuous technical control, calculation of the slope stability using geotechnical software, operation of monitoring systems, and maintain drainage systems are required.

In this study, the formerly recorded landslides are evaluated in three areas around Lake Balaton. In order to understand the mechanisms of sliding geological information, landslide types and the timing of the events are considered. Based on the data, it is possible to differentiate between the prevailing landslide types of northern, southern coasts, and eastern regions of the lake. An additional analysis comparing built-in areas and building free areas is also provided.

The gathered information helps in understanding the triggers and causes of landslides and allows for better planning and better mitigation of landslide affected areas.

\section{Geography and geology}

Lake Balaton is the largest sweetwater lake in Central Europe in the Transdanubian region of Hungary (Fig. 1). This freshwater lake also called the 'Hungarian Sea', and 


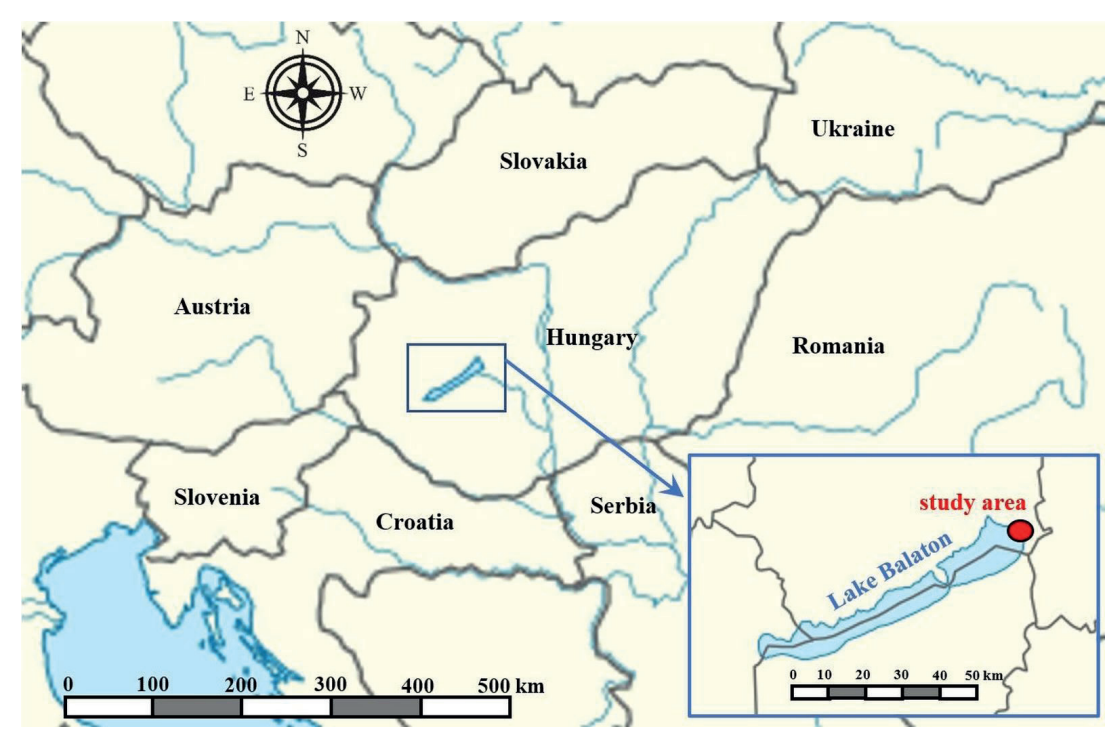

Fig. 1 Location of Lake Balaton in Central Europe and within Hungary

its region is an internationally popular tourist and resort center. Its rapidly warming shallow water, beautiful mountainous and wine region of the north and flat resort towns of the south is attractive to many. Coastal slopes along the lake are in motion, causing continuous problems in terms of the stability of these slopes. The complexity of the problem is also linked to land use since railway lines run through several places on the slopes of high banks or directly on the lakeshore. Additionally, steep slopes are also found in densely built and constantly expanding resort and residential areas.

Hungary's detailed surface geological map [11] illustrates the lithological differences along the coast very spectacularly at first glance, indicating the presence of lake sand, loess, various clays, and consolidated rocks (Fig. 2).

The following is a brief history of Lake Balaton and its geological environment. The Pannonian Sea, which has covered the area for millions of years during the Miocene period, has left extremely thick sand and clay deposits. The main elements of the shores are these Pannonian sediments. The higher lakeside banks are now formed within these sediments, often forming a plateau. The hinterland provided the sediments that filled the rapidly subsiding Pannonian Basin. Besides sedimentary rocks, volcanic rocks such as basalt and basaltic tuff mark this period linked to volcanic eruptions. These rocks are found in the western part of Lake Balaton in the north. Post volcanic activity was marked by geysers in the Tihany peninsula, forming a protective cover on the top of soft sediments. Two faults delineate the lake basin; one is located parallel to the northern shore and the southern one. A
Holocene trench-like depression is linked to these faults and due to the subsidence water accumulated in the lake. The dry winds of the ice age accumulated loess in places. The coastal zone of Lake Balaton was either formed by wave abrasion or by the deposition of lake sediments. High banks, their collapses, and slumps shaped the shores. The lake dried out several times during its history and was filled with water again, with significant water level changes. These days, the Sió Channel is the only runoff. Before its construction, the water levels were typically much higher than it is today [12].

\section{Materials and methods}

Various sources of information were used to gather data on historical landslides. Due to the construction of railway lines and recorded slope failures from the $19^{\text {th }}$ century (1860's) historic data on slope instability has been available for the past one and a half-century. Several maps have been collected showing the surroundings of Lake Balaton [10, 13-14], where major landslides are marked, indicating the year of the landslide events and their locations (Fig. 3(a)).

The Mining and Geological Survey of Hungary (MBFSZ) started its cadastral work in 1972. The registration of surface movement areas throughout Hungary was examined, and as a part of the project, the Lake Balaton area was also studied. As a result of this research, the Online Landslide Hazard Map of Hungary was published [15], and the National Surface Movement Cadaster of Hungary [16] also complied. The locations of past sliding events are shown on the online map identifying 28 types of mass movements. One example from the study area, the Tihany peninsula, 


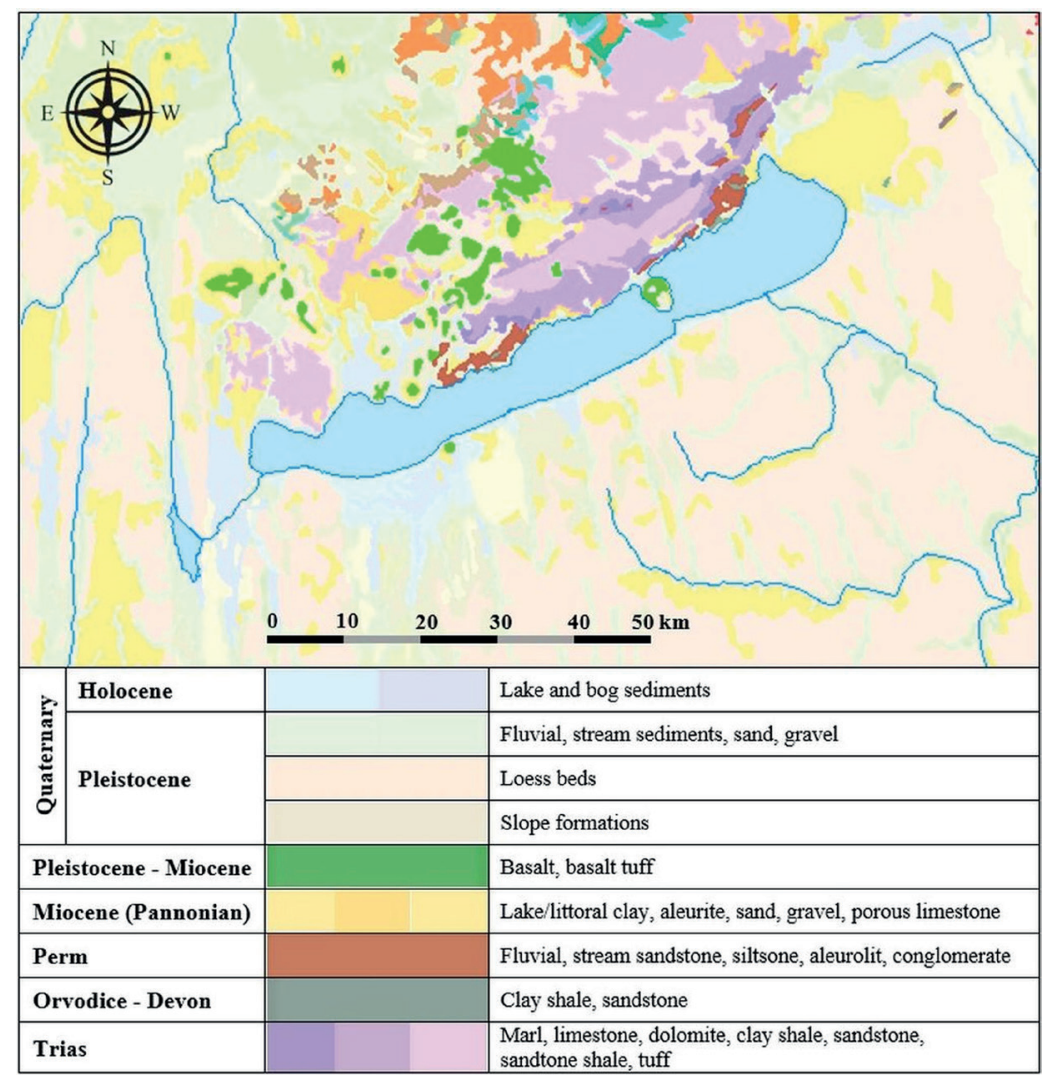

Fig. 2 The geological map of the Lake Balaton area

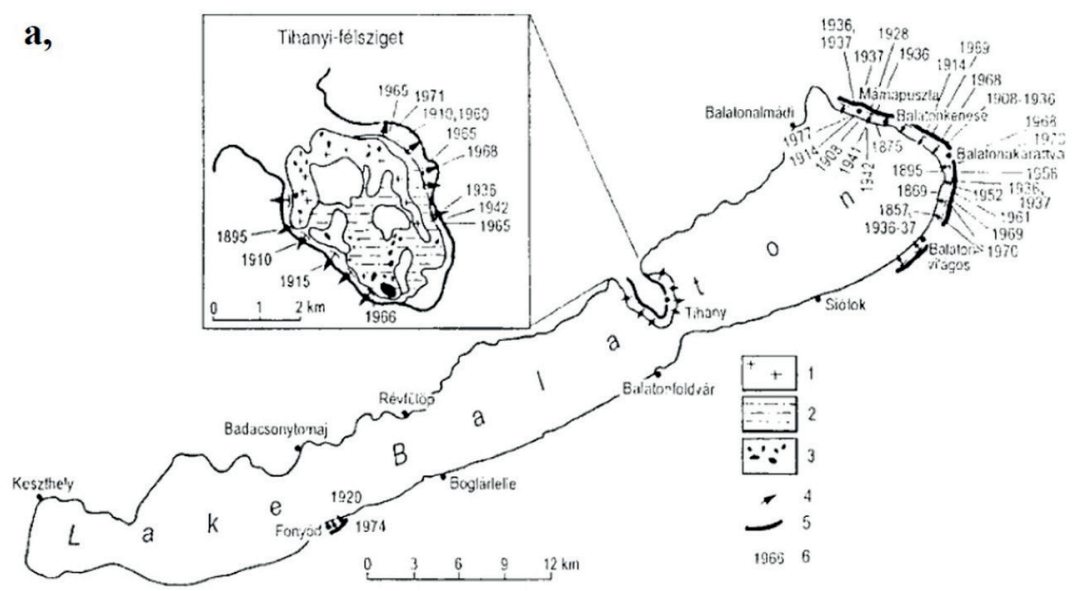

Key: 1 - basalt, basalt tuff; 2 - Pannönian formation; 3 - geysirite cones, post-volcanic features; 4 - sites of the occurence of major landslides; 5 - bluffs; 1966 - year of landslide event

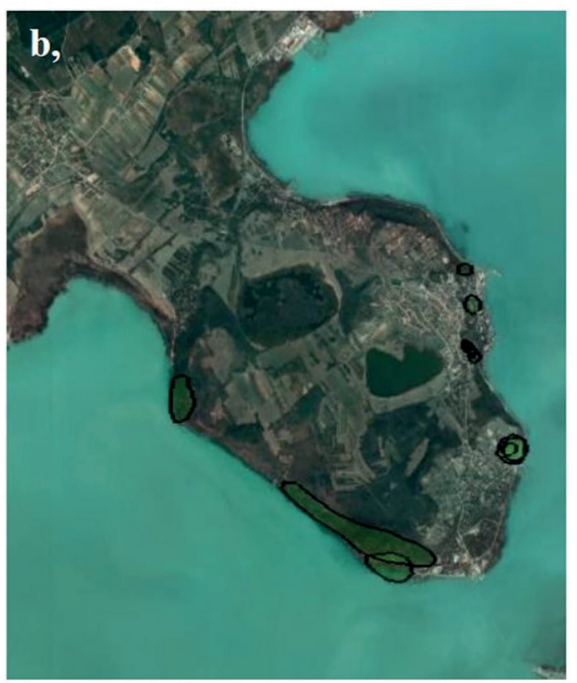

Fig. 3 a) Landslides along the coasts of Lake Balaton [10]; b) Satellite image showing unstable zones in the National Surface Movement Cadastre of Hungary [16]

is given in Fig. 4(a), displaying the information gathered from these maps. The points of past landslides are all accessible via a click, where an information window opens after the click. The following data are available in these information windows: movement type, settlement, periodicity, condition, built-in, possible cause, intervention. In addition, polygons denote surface and linear erosion, and locations that are currently affected by erosion or alluvial surfaces are also marked. The cadaster map [16], in contrast, is a downloadable $\mathrm{kmz}$ file that can be opened on a Google Earth map (shown in Fig. 3(b)) or in geospatial software. On separate layers, one can find points and polygonal zones that delimit selected surface movements. These are presented on satellite images marking 


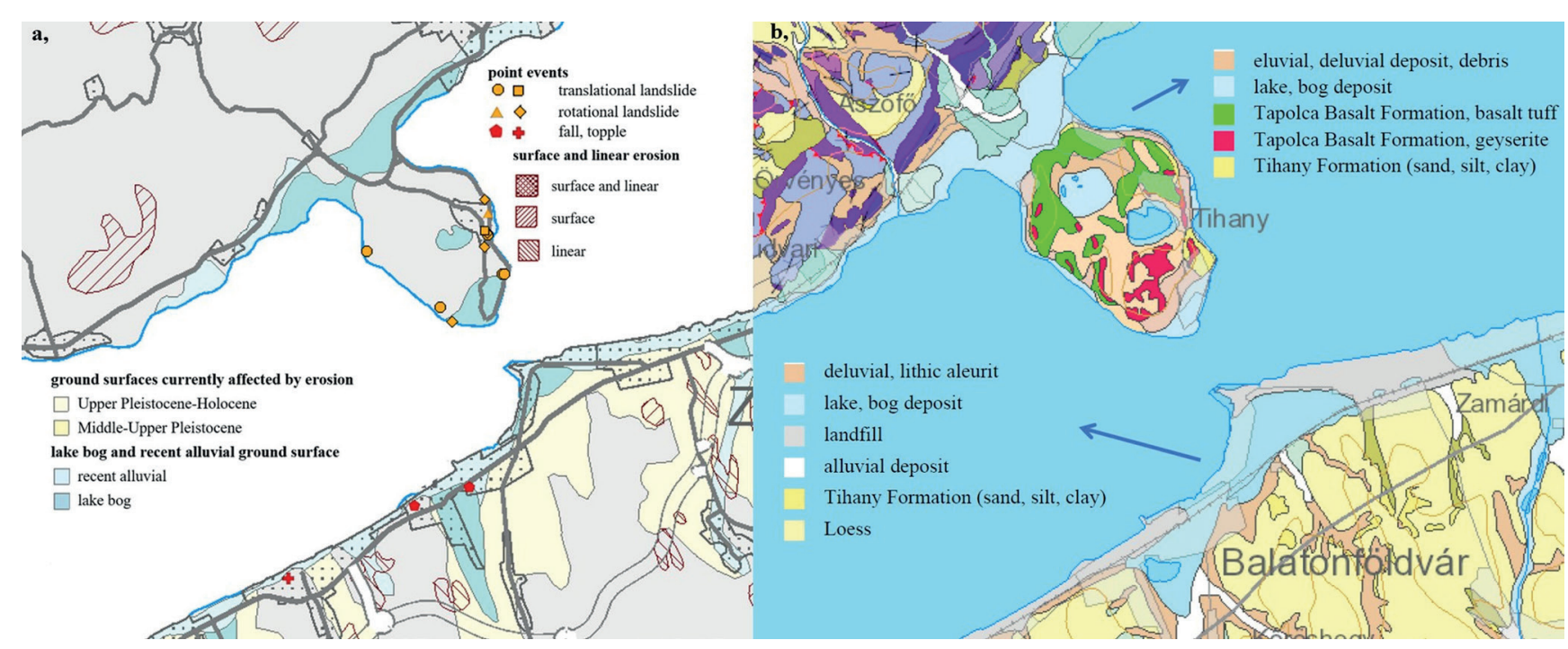

Fig. 4 Map details of the Tihany peninsula; a) Online Landslide Hazard Map of Hungary [15]; b) Surface geology of Hungary [17]

the surface motion events. The data listed for the online map can also be read here, including the beginning and the end of the movements and the dimensions of the area. The data system currently contains more than 2000 entries. The data of the movements along Lake Balaton were summarized in tables; thus, we created a new data compilation that was grouped and analyzed in several ways. The results of these analyses are presented in graphs taking into account the geological conditions obtained from geological maps (Fig. 4(b)) [17]. Thus, the research methodology is interpretive statistical processing of the data of the maps presented in Figs. 3 and 4.

\section{Results and discussion}

The main types of mass movements of raised shorelines along Lake Balaton are divided into the following categories: historic (paleo) slides, recent slides, landslides of slopes and falls, and additionally topplings.

According to the archive maps [10,13-14], most movements took place in the eastern basin between 1921 and 1940. Another period that was heavily affected by mass movements was between 1961 and 1980. At that time, several landslides occurred in the eastern basin and in the north (Table 1).

Table 1 The data set of archive movements by area and period

\begin{tabular}{lccc}
\hline & Eastern basin & North coast & South coast \\
\hline-1900 & 4 & 1 & \\
$1901-1920$ & 4 & 3 & 1 \\
$1921-1940$ & 10 & 1 & \\
$1941-1960$ & 3 & 2 & 1 \\
$1961-1980$ & 9 & 6 & \\
\hline
\end{tabular}

Most movements are registered in the eastern basin. The proportion of archive movements is the highest here. Most of the movements (30) took place here before the 1980s. Between 1920 and 1940, there were ten mass movements; between 1960 and 1980, nine mass movements occurred, while the map server recorded ten rotational landslides and three falls (Fig. 4).

The sedimentary series of the Tihany Formation (clay, sand, silt) is predominantly involved in constructing the high banks of the eastern basin. These are sediments of the deltas arriving at Lake Pannon. Layers of the Tihany Formation were deposited as a series of sequences in the diverse palaeo-environments of the Pannonian Sea forming deltas arriving into the lake. It consists of sediments of different particle sizes but predominantly fine sand and rock flour. [18] Quaternary formations of different thicknesses settle on the layers of the Tihany Formation. The cold winds of the ice age formed a thin loess cover, which has been already eroded in many places, and elsewhere it is only present in a maximum thickness of a few meters. The uppermost loess-sand sediment cover is divided by coarse, gravel-debris bed embankments of the Pleistocene stream bed. Beneath the lake-bog,-terrestrial variegated clays settled, while deeper layers of sand and clay alternate beneath mud layers with lignite settlements which play a significant role in the horizontal flow of waters. The sliding surfaces of the large slides were formed at the lake bed level of Lake Balaton; the smaller ones destroy the sandy-clay sedimentary series and shore sections above the railway track [5].

In 1942, Aladár Vendl [19] compared the range and landslides of the high shore of the eastern basin morphologically with the examples of the Transylvanian Mezöség, 
Italy, southern France and Central Siberia. In 1943, Lajos Lóczy Jr. drew attention to the fact that the shear surface of the slides often extends deep below the lake bed, thus causing bed rise. [19] As a result of such an event, two islands could have formed in front of Balatonakarattya, which can still be seen on the map of Ignác Müller issued in 1769, but slope scours terminated them by the mid-1800s [19].

On the north coast, most of the movements $(100 \%$ on archive maps) are concentrated on the Tihany Peninsula, most of them for the period 1960-80. Digital maps record nine rotational landslides, seven translational landslides, and five falls in the north (Fig. 5).

On the northern shore, the dynamically changing high shores of the Tihany Peninsula were shaped by large-scale landslides. Here, the basalt tuffs of the Tapolca Basalt Formation cover the sedimentary sequence of the Tihany Formation, which periodically stabilizes the upper edge of the high bank. Tectonic fractures and cracks mark the location of the slip planes. In the north, the volcanic witness buttes (Badacsony, Szigliget) were shaped by fossil slopes, creating dynamic, bumpy slopes. The columnar basalts of witness buttes are destroyed by freezing ad falling events, the basalt blocks, and loose ground forms the boulder field boundary zone on the loose Pannonian sediments [10].

The south bank has the most extended raised-shoreline in length but still has the least registered moving areas. On the south coast, falls/topples prevail, but rotational landslides, translational landslides and creeps also occur (Fig. 5).

Five-ten meters thick loess covers the sediments of the loose Tihany Formation and on the red clay cover [10]. Here, the Upper Pannonian sand and clay form thick layers, which is different from the eastern basin, where the Upper Pannonian is represented by thin alternating layers of clay and sand [20]. In Fonyód, these beds are interrupted by basalt tuff layers of the basaltic volcanism of the Balaton Uplands [21].

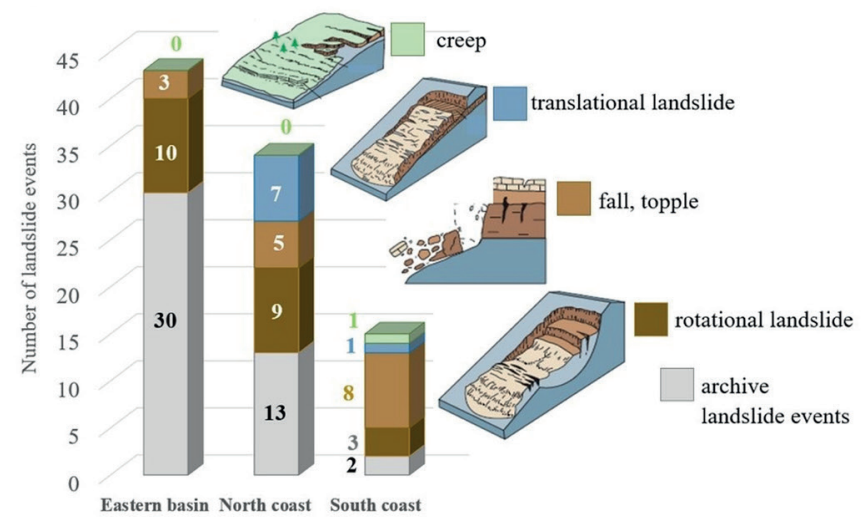

(a)
Fig. 5 shows the percentage distribution of the types of movements registered on the MBFSZ map server and the National Surface Movement Cadaster along Lake Balaton. The differences in the geological and morphological-structural geological settings cause variations in hydrogeological conditions, which can explain the distinct stabilities of slopes [14].

Nearly half of the movements are rotational landslide and slump. Deep-seated rotational motion is favored by undrained failures and is most common in saturated soils of low permeability (clays or silts). Under special circumstances, undrained failure can occur in granular soils, particularly if rapid motion is triggered by liquefaction. In such cases, the circular sliding failure mode is shortlived and serves as an initiating mechanism of mudflows [15]. This form of movement can occur in the nearly homogeneous layers and without external intervention if the layer material soaks for some reason and loses its shear resistance. The motion does not have a predefined sliding plane; it always occurs somewhere in the line of the highest internal stresses and the smallest resistances resulting from the tare weight of the layer, thus in a place appropriate to the degree of soaking and the instantaneous force conditions [22]. The subsurface flows wash out the fine fraction of the larger particles mainly from the sand layers, so the structure is compacted continuously or periodically [23]. $33 \%$ of the movements are fall, topple, collapse (bank/loess $\sim$ ), high bank rupture, caving, and landfall. The mechanism of block toppling in the soil is equal to block toppling in rock, although the low strength of weakly cemented or of partially saturated soil columns promotes failure by basalt crushing, without the need for horizontal discontinuities [23]. Behind the sandbanks of the high shores exposed to wind, rain and sun and thus, vertical to subvertical cracks are formed due to shrinkage stresses. Along these, the connection between the shore

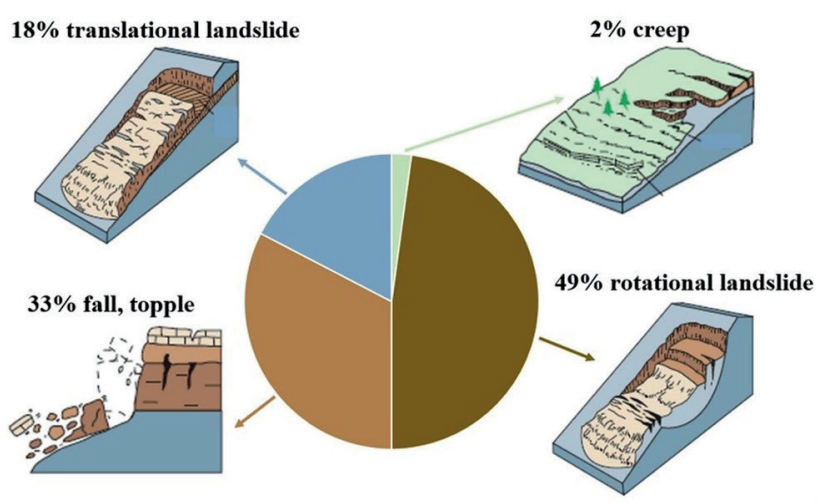

(b)

Fig. 5 Proportion of landslide forms a, in the three regions of Lake shoe b, and in the entire shoreline around Lake Balaton 
and the cracked soil plate is lost; hence, the full weight of the cracked part can only rest on its floor. When the floor can no longer withstand the pressure, the plate will collapse. This can occur even at low column heights if the base of the plate soaks and loses its strength [15]. Soil humps with collapse hazards also form above the breaking front of previous slides [10]. The presence of translational landslides is below $20 \%$ when the upper layers start to move along a given layer, most often at the boundary of a layer of sand and clay or along with thin aquiferous sand lenses in clay layers [15]. The remaining $2 \%$ of the movements are creeping. It is an extremely slow movement of the topsoil layers on a slope (typically less than $1 \mathrm{~m}$ thick) and results from climate-driven cyclical volume changes (wetting and drying, frost heave) [24].

Cruden and Varnes [25] divided the landslide causes into four major categories: nine geological causes, nine morphological causes, nine physical causes and eight man-made (called human by USGS [26]). The USGS classification is very similar to this; however, it mentions only a few of the physical causes of weathering, which is not a separate category for them. Kézdi [27] divides the effects on the stability of slopes into three groups: physical effects of atmospherics, other natural effects, and artificial interventions. Water has a significant triggering role in all categories, reducing the stability of the slope: surface water, infiltrating precipitation groundwater, karstic water or springs. Besides natural processes, human interventions can also cause changes in the water system, such as diversion of water or modification of water pressure (hydrostatic or pore water pressure). When traversing the high shores, trees with curved trunks in several places show signs of the slow movement.

The factors affecting changes in cliff geometry include wave action, frost action, seepage effects, sheet wash, and weathering [2]. The abrasion risk of the high shores of Lake Balaton has largely disappeared with the construction of coastal protection works and the regulation of the water level of the lake [20].

As can see in Fig. 6, most of the previous movements were caused by soaking. Soaking is responsible for almost half of the translational landslides, but one-third of fall/ topple and nearly one-quarter of rotational landslides also caused by soaking, proving the stability-reducing effect of water.

Slope instability events, including landslides and erosion, can be triggered by changing rainfall patterns, water level increases, and land-use patterns, such as deforestation and desertification. All these processes increase the risk of stability of slopes that have been stable for long periods. While the risk can be minimized by accounting for these changes when designing new artificial slopes, natural and existing slopes are at higher risk of instability in a changing climate [28].

The soaking and sliding of the slope depending on the hydrogeological conditions [22]. The cause of the collapses at the shores of Lake Balaton is triggered by water infiltration in the mountainous areas, as was already stated

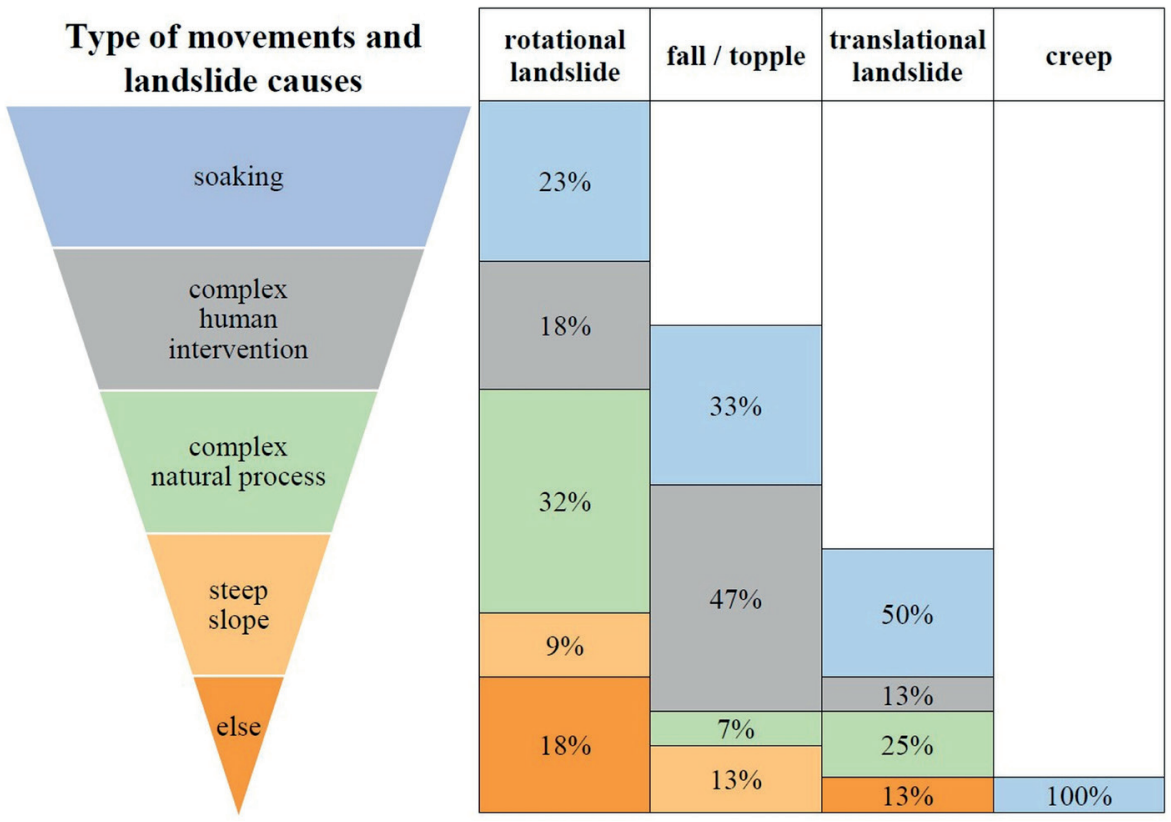

Fig. 6 Type of movements and the causes of landslides 
hundred years ago by Toborffy [29]. Later, Juhász [30] found a strong correlation between rainy periods and the occurrence of landslide events. According to Franconi et al. [8] the primary factors in the triggering of mass movements at coastal areas are the above-average amount of precipitation, the extreme rains, the increased level of groundwater resulting from infiltration, the formation of subsurface leakage paths, the modified flow conditions, and the replenishment of the subsurface storage system. In our case, at the shorelines of Lake Balaton, the waters that do not appear on the surface as springs are the most dangerous triggers of landslides [19]. In this case, the sandy soils soaked with water moisten the clay soils and makes these slippery thus, the slope above moves slowly downward. Due to disturbed soil layers/stratification (mainly in the debris slopes of previous movements), there are sealed suitable aquifers such as sand and silty sand lenses in which water may be under pressure. Thus, when the groundwater level rises, the shear resistance decreases, and a slip occurs [31].

Nearly half of the falls/topples at Lake Balaton is due to human interventions. Human activity (railway construction, etc.) changed the previous dynamic equilibrium conditions and led to a new surface morphology [10]. However, the impact of human activities is often favorable; for example, the construction of coastal erosion control structures such as rip-rap walls, rock armors or coastal roads with foundations eliminated abrasion. Deep foundations and the removal of soil masses, rearrangement of the terrain also increase the slope stability [32].

Rotational landslides are mainly caused by a complex natural process, as explained in the description of the forms of movement, but the water is also an important influencing parameter of these complex processes. Steep slope morphology also has a high risk of sliding.
The data on the landslide hazard map and National Surface Movement Cadaster show that more than half of the registered landslide hazard area of shorelines is still in motion (Fig. 7). The recorded active slidings have 53\% in the built-up area and $65 \%$ in the non-built-up area. The shores at rest, partially or entirely exempted, represent $41 \%$ in built-up and $21 \%$ in the non-built-up area. There are $6 \%$ and $14 \%$ of areas where there are no protective measures or their conditions are unknown, at built-up and non-built-up areas, respectively (Fig. 7). At these sites, the landslide risk is unknown but could be high.

On the Ground motion map of Hungary [33] the lake is contoured with a relatively stable zone in slow motion with displacement rates of $1-1.5 \mathrm{~mm} /$ year. This color-coded ground motion velocity map of satellite radar points shows the velocity estimates for more than 14 million point targets throughout Hungary (Fig. 8).

However, surface movements moved hundreds of cubic meters of soil mass in recent years near Lake Balaton. The best-known examples are from the Balatonakarattya. In

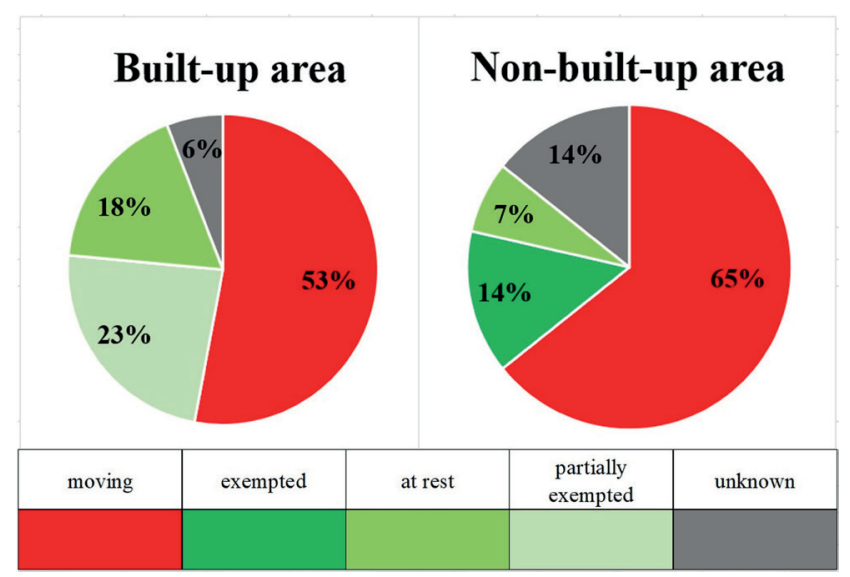

Fig. 7 Hazardous areas in built-up and non-built-up areas and their conditions
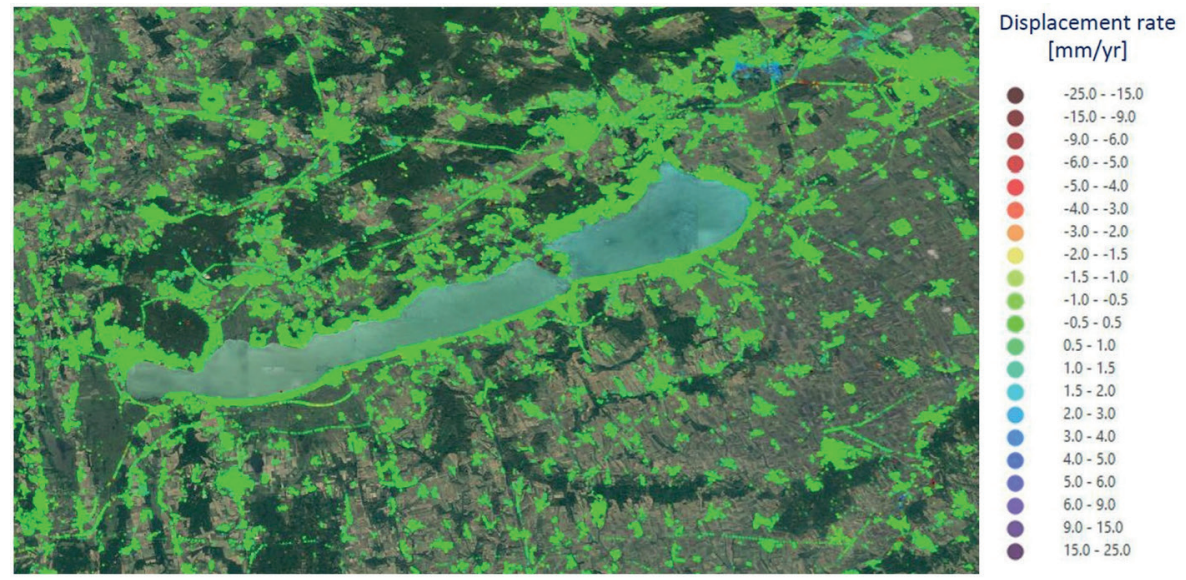

Fig. 8 Ground motion map of Hungary by Geo-Sentinel [33] (detail) 
May 2010, the railway track slipped along a 70 meter-wide zone, and the railway track collapsed, and a debris slope was formed. In March 2011, a 100-meter-long slip occurred in the remediation piles and injections were applied. In 2017, $200-300 \mathrm{~m}^{3}$ of soil slipped due to irregular rainwater drainage. Based on these activities, the relative stability may be exaggerated. The velocities at each point were calculated from the historical data of the movements (2014-2021). Based on this data set - an average of 100 different times over a time interval of nearly six years -, slow movements can also be interpreted since the measurements are less frequent than 20 days. Rapid and catastrophic landslides affecting large areas can happen in moments damaging roads and railways. However, in most cases, slow movements are observed, but this does not mean that the slope is stable since motion can be accelerated, and any mechanism can trigger rapid landslides even in these slow-moving areas, without any previous signs of acceleration.

Similar features were observed at other lithologies such as marls [34] and flysch [35]. The recording of such displacements of soft rock slopes and cliff faces are possible by using remote sensing techniques such as terrestrial laser scanner TLS [36, 37] or unmanned aerial vehicles (UAV) [6, 38-40].

Fig. 9 displays all the movements recorded so far, while the shoreline lengths are from the summary table of the high shores of Lake Balaton [41-42].

The eastern basin is where the most collapses were generated, while the total length of raised shorelines is the longest on the south coast. Many mass movements are concentrated on the Tihany Peninsula on the north shore (Table 2).

\section{Conclusions}

A series of earlier mass movements have shaped the morphology of the high shores of Lake Balaton, and those are also landslide hazard areas. Most of them are still in periodic motion. The highest proportion of recorded landslides are in the eastern basin. While the longest shoreline is on the south, most movements occur in the eastern basin and the Tihany Peninsula since the shores rise higher. Their geological conditions make this more prone to landslides. The most typical landslide form of shores along Lake

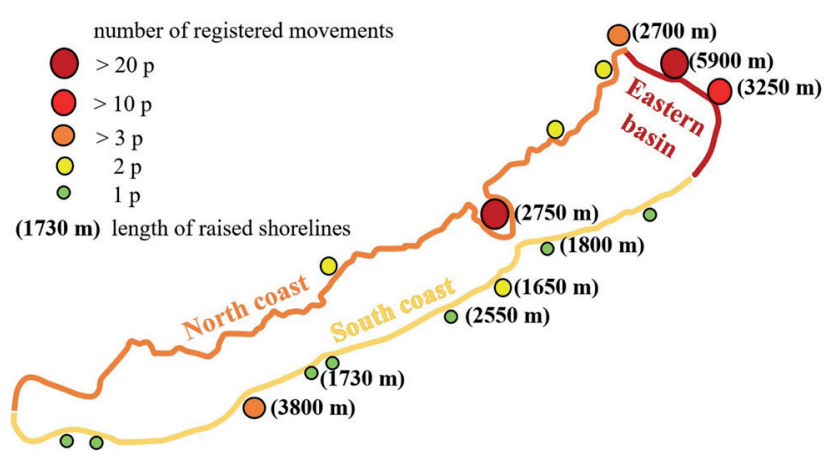

Fig. 9 Number of registered movements, length of registered shorelines along Lake Balaton

Table 2 Summary table of high bank movements, shoreline length and moving areas (the maximum values are marked in bold)

\begin{tabular}{lccc}
\hline & $\begin{array}{c}\text { number of registered } \\
\text { movements }\end{array}$ & $\begin{array}{c}\text { shoreline } \\
\text { length (m) }\end{array}$ & $\begin{array}{c}\text { moving } \\
\text { areas (\%) }\end{array}$ \\
\hline Eastern basin & $\mathbf{4 3}$ & $9150 \mathrm{~m}$ & $\mathbf{6 2 \%}$ \\
North coast & 34 & $5450 \mathrm{~m}$ & $59 \%$ \\
South coast & 16 & $\mathbf{1 1 5 3 0 ~} \mathbf{m}$ & $46 \%$ \\
\hline
\end{tabular}

Balaton is the rotational landslide. These are the most common on the north and east coasts, while falls and toppling prevailed in the south. The movements are mainly caused by soaking. It can be linked to several mechanisms, such as the rainy season, high lake water level, seepage of subsurface waters, pipeline failure. Additionally, where there are no coast protective structures, wave action erodes the coasts and triggers landslides. Human interventions, such as cutting slopes or building on the top of high banks, can also cause large-scale mass movements. Fast mass movements are more characteristic (it has happened several times in recent years), but slow movements are also common and can be accelerated. Field monitoring systems are essential in identifying landslide risk areas, and the available techniques such as inclinometers can detect sliding areas even if the motion is very slow. Movements endanger railway lines, roads and recreation areas; therefore, technical control is essential.

\section{Acknowledgement}

The research reported in this paper has been supported by the National Research Development and Innovation Office of Hungary (Grant No. TKP2020 BME-IKA-VIZ) 


\section{References}

[1] Barlow, J., Gilham, J., Ibarra Cofrã, I. "Kinematic Analysis of Sea Cliff Stability Using UAV Photogrammetry", International Journal of Remote Sensing, 38(8-10), pp. 2464-2479, 2017.

https://doi.org/10.1080/01431161.2016.1275061

[2] Edil, T. B. "Erosion of Coastal Slopes and Landslide", presented at Geo-Congress 2013, San Diego, CA, USA, March, 3-7, 2013. https://doi.org/10.1061/9780784412787.133

[3] Edil, T. B., Vallejo, L. E. "Mechanics of coastal landslides and the influence of slope parameters", Engineering Geology, 16(1-2), pp. 83-96, 1980.

https://doi.org/10.1016/0013-7952(80)90009-5

[4] Bögöly, Gy., Léber, T., Rozgonyi-Boissinot, N., Vásárhelyi, B. "Sziklarézsűk vizsgálata - elmélet és gyakorlat" (Investigation of Rock Slopes - Theory and Practice), Útügyi Müszaki Füzetek 1, MAÚT, Budapest, Hungary, 2021. (in Hungarian)

[5] Catani, F., Tofani, V., Lagomarsino, D. "Spatial patterns of landslide dimension: A tool for magnitude mapping", Geomorphology, 273, pp. 361-373, 2016.

https://doi.org/10.1016/j.geomorph.2016.08.032

[6] Giordan, D., Adams, M. S., Aicardi, I., Alicandro, M., Allasia, P., Baldo, M., De Berardinis, P., Dominici, D., Godone, D., Hobbs, P., ..., Troilo, F. "The use of unmanned aerial vehicles (UAVs) for engineering geology applications", Bulletin of Engineering Geology and the Environment, 79, pp. 3437-3481, 2020.

https://doi.org/10.1007/s10064-020-01766-2

[7] Utili, S., Crosta, G. B. "Analysis Tools for Mass Movement Assessment", In: Shroder, J. F., Davies, T. (eds.) Landslide Hazards, Risks and Disasters, Elsevier, Amsterdam, Netherlands, 2015, pp. 441-465.

https://doi.org/10.1016/B978-0-12-396452-6.00013-6

[8] Franconi, M., Coggan, J. S., Eyre, M., Staed, D. "A combined field/ remote sensing approach for characterizing landslide risk in coastal areas", International Journal of Applied Earth Observation and Geoinformation, 67, pp. 79-95, 2018.

https://doi.org/10.1016/j.jag.2017.12.016

[9] Jabeyedoff, M., Carrea, D., Derron, M.-H., Oppikofer, T., Penna, I. M., Rudaz, B. "A review of methods used to estimate initial landslide failure surface depths and volumes", Engineering Geology, 267, Article number: 105478, 2020.

https://doi.org/10.1016/j.enggeo.2020.105478

[10] Juhász, Á. "Településeket, létesítményeket veszélyeztető tömegmozgások a balatoni magaspartok mentén" (Mass movements endangering human settlements and structures along the high bluff flanking Lake Balaton), [pdf] In: Horváth, G., Papp, S. (eds.) Földrajzi közlemények, 128, Magyar Földrajzi Társaság, Budapest, Hungary, 2004, pp. 19-30. (in Hungarian) Available at: http://real-j. mtak.hu/10126/1/FoldrajziKozlemenyek_2004.pdf

[11] Magyar Bányászati és Földtani Szolgálat "Magyarország felszíni földtana, Balaton" (Surface geology of Hungary, Lake Balaton), 1:5000 000, [online] Available at: https://map.mbfsz.gov.hu/fdt500/

[12] Cholnoky, J. "Balaton" (Lake Balaton), [pdf] Franklin, Budapest, Hungary, 1936. (in Hungarian) Available at: http://mek.oszk.hu/ 00500/00574/00574.pdf
[13] Fodor, T., Kleb, B. "Magyarország mérnökgeológiai áttekintése" (Engineering geological overview of Hungary), [pdf] Magyar Állami Földtani Intézet, Budapest, Hungary, 1986. (in Hungarian) Available at: http://mek.oszk.hu/19000/19071/19071.pdf

[14] Horváth, Zs. "Engineering geological evolution of the danger surface movement on the raised shorelines along lake Balaton", In: Pécsi, M. (ed.) Quaternary Studies in Hungary, INQUA Hungarian National Committee, Budapest, 1982, pp. 245-253. [online] Available at: http://real-eod.mtak.hu/id/eprint/4503

[15] Magyar Bányászati és Földtani Szolgálat "Magyarország mozgásveszélyes területei" (Areas of danger of movement in Hungary), 1:5000 000, [online] Available at: https://map.mbfsz.gov.hu/FDT_ veszely_orszag/

[16] MBFSZ "Országos Felszínmozgás Kataszter" (National Surface Movement Cadastre), Magyar Bányászati és Földtani Szolgálat Budapest, Hungary, [online] Available at: https://mbfsz.gov.hu/ hatosagi-ugyeknyilvantartasok/orszagos-felszinmozgas-kataszter

[17] Magyar Bányászati és Földtani Szolgálat "Magyarország felszíni földtana, Budapest" (Surface geology of Hungary, Budapest), 1:5000 000, [online] Available at: https://map.mbfsz.gov.hu/fdt100/

[18] Sztanó, O., Magyar, I., Szónoky, M., Lantos, M., Müller, P., Lenkey, L., Katona, L., Csillag, G. "A Tihanyi Formáció a Balaton környékén: típusszelvény, képződési körülmények, rétegtani jellemzés" (Tihany Formation in the surroundings of Lake Balaton: type locality, depositional setting and stratigraphy), Földtani Közlöny, 143(1), pp. 73-98, 2013. (in Hungarian) [online] Available at: https://ojs.mtak. hu/index.php/foldtanikozlony/article/view/2319

[19] Domján, J., Pappfalvy, F. "A balatonfüzfői magaspart talajmechanikai vizsgálata" (Soil mechanics study of the Balatonfüzfő high bank), Hidrológiai Közlöny, 33(9-10), pp. 389-395, 1953. (in Hungarian) Available at: https://library.hungaricana.hu/hu/view/Hidrologiai Kozlony_1953/?pg=0\&layout=s

[20] Horváth, Zs. "A balatoni magaspartok összehasonlító mérnökgeológiai értékelése" (Comparative engineering geological assessment of the high shores of Lake Balaton), [pdf] Mérnökgeológiai Szemle, 33, pp. 125-143, 1984. (in Hungarian) Available at: https://epa. oszk.hu/03200/03208/00033/pdf/EPA03208_mernokgeologiai_ szemle_33_1984_125-143.pdf

[21] Horváth, Zs., Scheuer, Gy. "A balatonföldvári és fonyódi magaspartok állékonyságának mérnökgeológiai vizsgálata" (Engineering geological study of the stability of the high shores of Balatonföldvár and Fonyód), [pdf] Földtani Közlöny, 105, pp. 335-343, 1975. (in Hungarian) Available at: https://epa.oszk.hu/01600/01635/00211/ pdf/EPA01635_foldtani_kozlony_1975_105_3_335-343.pdf

[22] Galli, L. "A dunai és balatoni magaspartok állékonyságának törvényszerüségei" (The regularities of the stability of the high banks of the Danube and Lake Balaton), Hidrológiai Közlöny, 32(1-2), pp. 409-416, 1952. (in Hungarian) [online] Available at: https://library. hungaricana.hu/hu/view/HidrologiaiKozlony_1952

[23] Lóczy, L. "A Balaton környékének geológiai képződményei" (Geological formations around Lake Balaton), In: A Balaton tudományos tanulmányozásának eredményei 1.1., Magyar Földrajzi Társaság Balaton-Bizottsága, Budapest, Hungary, 1913. (in Hungarian) [online] Available at: https://library.hungaricana.hu/hu/ view/SZAK_BAKO_BalatonTudTanEredm_01/?pg=0\&layout=s 
[24] Hungr, O., Leroueil, S., Picarelli, L. "The Varnes classification of landslide types, an update", Landslides, 11(2), pp. 167-194, 2014. https://doi.org/10.1007/s10346-013-0436-y

[25] Cruden, D. M., Varnes, D. J. "Landslide Types and Processes", Transportation Research Board, U.S. National Academy of Sciences, Washington, DC, USA, Special Report 247, pp. 36-75, 1996.

[26] USGS "Landslide Types and Processes", U.S. Geological Survey, Reston, VI, USA, 2006. [online] Available at: https://pubs.usgs.gov/ fs $/ 2004 / 3072 /$

[27] Kézdi, Á. "Talajmechanika I." (Soil mechanics I.), Tankönyvkiadó, Budapest, Hungary, 1960. (in Hungarian)

[28] Mickovski, S. B., Santos, O., Ingunza, P. M. D., Bressani, L. "Coastal slope instability in contrasting geo-environmental conditions", In: Proceedings of the XVI ECSMGE Geotechnical Engineering for Infrastructure and Development, Edinburgh, Scotland, 2015, pp. 1801-1806.

https://doi.org/10.1680/ecsmge.60678

[29] Toborffy, G. "A balatoni partrogyások sztatikai és hidrológiai viszonyai", (Static and hydrological conditions of the shores of Lake Balaton.), [pdf] In: A Magyar Állami Földtani Intézet évi jelentése (1917-19.), Magyar Állami Földtani Intézet, Budapest, Hungary, 1921, pp. 162-169. (in Hungarian) Available at: http:// epa.oszk.hu/02900/02934/00079/pdf/EPA02934_mafi_evi_ jel_1917_19_162-169.pdf

[30] Juhász, Á. "A klimatikus hatások szerepe a magaspartok fejlődésében" (Static and hydrological conditions of the shores of Lake Balaton), [pdf] Földtani Kutatás, 36(3), pp. 14-19, 1999. (in Hungarian) Available at: http://epa.oszk.hu/02700/02732/00141/pdf/ EPA02732_foldtani_kutatas_36_3_14-19.pdf

[31] Kézdi, Á. "A Balaton északkeleti peremén bekövetkező mozgások vizsgálata" (Movements on the northeastern edge of Lake Balaton examination ), Hidrológiai Közlöny, 32(5-6), pp. 168-177, 1952 (in Hungarian) [online] Available at: https://library.hungaricana.hu/en/ view/HidrologiaiKozlony_1952/?query=SZO\&pg=177\&layout=s

[32] Scheuer, Gy. "A tihanyi kopaszhegyi csuszamlás mérnökgeológiai vizsgálata" (Engineering geological study of the Kopaszhegy landslide in Tihany), Mérnökgeológiai Szemle, 189, pp. 77-91, 1977. (in Hungarian)

[33] Grenerczy, Gy., Farkas, P., Frey, S. "Ground motion map of Hungary" Geo-Senitel, Budapest, Hungary, 2021.

https://doi.org/10.5281/zenodo.4625653

[34] Vlastelica, G., Miščević, P., Štambuk Cvitanović, N. "Durability of soft rocks in Eocene flysch formation (Dalmatia, Croatia)", Engineering Geology, 245, pp. 207-217, 2018.

https://doi.org/10.1016/j.enggeo.2018.08.015
[35] Živec, T., Anžur, A., Verbovšek, T. "Determination of rock type and moisture content in flysch using TLS intensity in the Elerji quarry (south-west Slovenia)", Bulletin of Engineering Geology and the Environment,78, pp. 1631-1643, 2019.

https://doi.org/10.1007/s10064-018-1245-2

[36] Kordić, B., Lužar-Oberiter, B., Pikelj, K., Matoš, B., Vlastelica, G. "Integration of Terrestrial Laser Scanning and UAS Photogrammetry in Geological Studies: Examples from Croatia", Periodica Polytechnica Civil Engineering, 63(4), pp. 989-1003, 2019. https://doi.org/10.3311/PPci.14499

[37] Mazzanti, P., Schilirò, L., Martino, S., Antonielli, B., Brizi, E., Brunetti, A., Margottini, C., Scarascia Mugnozza, G. "The Contribution of Terrestrial Laser Scanning to the Analysis of Cliff Slope Stability in Sugano (Central Italy)", Remote Sensing, 10(9), Article number: 1475, 2018. https://doi.org/10.3390/rs10091475

[38] Giordan, D., Hayakawa, Y., Nex, F., Remondino, F., Tarolli, P. "Review article: the use of remotely piloted aircraft systems (RPASs) for natural hazards monitoring and management", Natural Hazards and Earth System Sciences, 18, pp. 1079-1096, 2018. https://doi.org/10.5194/nhess-18-1079-2018

[39] Török, Á., Barsi, Á., Bögöly, G., Lovas, T., Somogyi, Á., Görög, P. "Slope stability and rockfall assessment of volcanic tuffs using RPAS with 2-D FEM slope modelling", Natural Hazards and Earth System Sciences, 18, pp. 583-597, 2018.

https://doi.org/10.5194/nhess-18-583-2018

[40] Mancini, F., Dubbini, M., Gattelli, M., Stecchi, F., Fabbri, S., Gabbianelli, G. "Using Unmanned Aerial Vehicles (UAV) for HighResolution Reconstruction of Topography: The Structure from Motion Approach on Coastal Environments", Remote Sensing, 5(12), pp. 6880-6898, 2013. https://doi.org/10.3390/rs5126880

[41] Kenesei, J., Marokházi, G., Nagy, J. "Mozgásveszélyes Duna-menti és Balaton parti magaspartok veszélyelháritási munkáinak tanulmányterve" (Study plan of emergency works for landslide hazard areas along the Danube and Lake Balaton), Kézirat, p. 71 , 2005. (in Hungarian)

[42] Balogh, J., Jakab, G., Prodán, T., Kis, É., Szalai, Z., Szeberényi, J., Varga, Gy., Viczián,. I. "Mérnökgeomorfológiai kutatások az omlásés csuszamlásveszélyes dunai és balatoni magaspartok partfal-rehabilitációjában", (Engineering geomorphological research in the shoreline rehabilitation of the dangerous banks of the Danube and Lake Balaton), In: VII. Magyar Földrajzi Konferencia Kiadványa, Miskolc, Hungary, 2014, pp. 60-70. (in Hungarian) [online] Available at: http://real.mtak.hu/id/eprint/20847 